\title{
Liczebność względnie beztlenowych, mezofilnych, przetrwalnikujących bakterii celulolitycznych w glebie spod uprawy drzew owocowych nawożonej kompostem na bazie miału z węgla brunatnego
}

\author{
Jakub Dobrzyński ${ }^{1}$,Wojciech Stępieńn ${ }^{2}$, Monika Sitarek ${ }^{3}$, Lidia Sas-Paszt ${ }^{4}$, \\ Patrycja Słodownik ${ }^{1}$, Ewa B. Górska ${ }^{1}$ \\ 1 Samodzielny Zakład Biologii Mikroorganizmów Szkoła Główna Gospodarstwa Wiejskiego w Warszawie \\ Nowoursynowska 159, 02-776 Warszawa, p.slodownik@onet.pl \\ 2 Wydział Rolnictwa i Biologii, \\ Szkoła Główna Gospodarstwa Wiejskiego w Warszawie, Katedra Gleboznawstwa \\ 3 Wydział Ogrodnictwa, Biotechnologii i Architektury Krajobrazu \\ Szkoła Główna Gospodarstwa Wiejskiego w Warszawie, Katedra Roślin Warzywnych i Leczniczych \\ 4 Instytut Ogrodnictwa, Zakład Agrotechniki \\ Konstytucji 3 Maja 1/3, 96-100 Skierniewice
}

\section{Streszczenie}

Ekologia względnie beztlenowych, mezofilnych, przetrwalnikujących bakterii celulolitycznych (WBMPBC) jest mało poznana. W literaturze przedmiotu znajdują się tylko nieliczne informacje dotyczące wpływu nawożenia oraz rodzaju uprawianej rośliny na występowanie w glebie WBMPBC. Dlatego celem naszych badań było wykazanie wpływu dodatku do gleby kompostów na bazie miału węgla brunatnego na właściwości chemiczne i liczebność względnie beztlenowych, mezofilnych, przetrwalnikujących bakterii celulolitycznych (WBMPBC) w glebie ryzosferowej i pozaryzosferowej wybranych roślin. Gleba pobrana z obiektów doświadczalnych była słabo kwaśna (pH - 6,2-6,4) i nieznacznie się różniła się zawartością makroelementów. Liczebność badanej grupy drobnoustrojów w glebie zależała od rodzaju kompostu i wynosiła od 9,42 do 3186,9 jtk (jednostki tworzące kolonie) w gramie suchej masy gleby (s. m. gleby). Wszystkie komposty stymulowały liczebność bakterii celulolitycznych w glebie pozarysoferowej. W przypadku ryzosfery kompost zawierający efektywne mikroorganizmy (EM) redukował liczebność WBMPBC. Największą liczebność badanej grupy drobnoustrojów stwierdzono w ryzosferze spod uprawy wiśni, nawożonej kompostem przygotowanym z węgla brunatnego z odpadem po produkcji owocników Pleuretus ostreatus (3186,9 jtk w g. s. m. gleby).

\section{Słowa kluczowe}

węgiel brunatny, celulazy, komposty, WBMPBC 


\section{Wstęp}

WBMPBC z rodzaju Bacillus i Paenibacillus (z łac. prawie- Bacillus) licznie zasiedlają różne typy gleb. Dzięki syntezie różnych egzoenzymów mogą rozkładać proste jak i złożone związki organiczne, pełniąc tym samym ważną funkcję w obiegu pierwiastków w przyrodzie (Lisdiyanti i in. 2012). Bakterie celulolityczne odgrywają istotną rolę w ekosystemach glebowych. Dzięki syntezie celulaz uwalniają z biomasy roślinnej zalegającej w glebie łatwo przyswajalną glukozę, która jest źródłem energii dla wielu mikroorganizmów wpływających korzystnie na żyzność gleby i wzrost roślin. Do tej pory wyizolowano i scharakteryzowano kilkadziesiąt szczepów Bacillus i Paenibacillus zdolnych do rozkładu celulozy (Emtiazi 2007; Yin i in. 2010: 466-471; de Castro i in. 2011; Moon i in. 2011; Asha i in. 2012; Kumar i in. 2012).

W ogrodnictwie i rolnictwie stale poszukuje się nowych ekologicznych preparatów do nawożenia roślin, które stymulowałyby właściwości biologiczne, fizyczne i chemiczne gleby - przez co korzystnie wpływałyby na wzrost i plonowanie roślin. Dobrą alternatywą dla tradycyjnych nawozów organicznych wydają się być produkty kompostowania (Zhen i in. 2014).

Możliwość zastosowania miału z węgla brunatnego do pozyskiwania wartościowego kompostu tłumaczy się jego właściwościami fizycznymi m.in. silnie rozwinięty układ porowaty, który warunkuje zdolność sorpcji i wymiany jonów między roztworem glebowym a fazą stałą gleby oraz zdolnością kompleksowania metali ciężkich, co zmniejsza ich pobieranie przez rośliny. Układ porowaty wiąże również składniki wprowadzane z nawozami mineralnymi, dzięki czemu są lepiej wykorzystywane przez rośliny. Węgiel brunatny jest wolny od patogenów, a słabo kwaśny odczyn oraz znaczna powierzchnia właściwa mogą oddziaływać korzystnie na wzrost aktywności drobnoustrojów ważnych dla procesów glebowych, m.in. takich jak: Azotobacter i Clostridium, które są zdolne do wiązanie azotu atmosferycznego czy Bacillus i Paenibacillus (Kwiatkowska i in. 2006).

Celem badań jest ocena wpływu kompostów przygotowanych z miału węgla brunatnego z różnymi dodatkami, na liczebność WBMPBC $\mathrm{w}$ glebie ryzosferowej i pozaryzosferowej wiśni, jabłoni.

\section{Metody i materiały}

Badania przeprowadzono w latach 2013-2015 roku na glebie płowej wytworzonej z piasku gliniastego mocnego pobranej z poletek doświadczalnych (trzy powtórzenia) Instytutu Ogrodnictwa w Skierniewicach, na których uprawiano jabłoń (Topaz) oraz wiśnię (Debreceni). Komposty użyte do doświadczenia zostały przygotowane na bazie miału z węgla brunatnego zawierającego odpady po produkcji owocników grzybów - słoma pszenna przerośnięta grzybnią Pleurotus ostreatus z/ bez preparatu EM. Każdy kompost został zastosowany w dawce odpowiadającej $8 \mathrm{o} \mathrm{kg}$ azotu na ha.

W badanej glebie zostały oznaczone następujące parametry:

1. całkowita zawartość węgla i azotu metodą bezpośrednią: C - PN-ISO 10694:2002, N - PN-ISO 11261:2002;

2. przyswajalne formy $\mathrm{P}$ i $\mathrm{K}$ metodą Egnera-Riehma: PN-R-04022/ Az1:2002;

3. magnez przyswajalny by Schachabela: PN-R-04020/Az1:2004;

4. dostępne formy mikroelementów w 1 molowym HCl: PN-R-04021:1994;

5. $\mathrm{pH}$ w $1 \mathrm{M} \mathrm{KCl} \mathrm{PN-ISO} \mathrm{10390:1997.}$

Najbardziej prawdopodobna liczebność (NPL) WBMPBC oznaczono w glebie ryzosferowej i pozaryzosferowej metodą rozcieńczeń dla trzech powtórzeń stosując pożywkę wg. Parka: $\left(\mathrm{NH}_{4}\right)_{2} \mathrm{SO}_{4}-\mathrm{O}, 5 \mathrm{~g} ; \mathrm{KH}_{2} \mathrm{PO}_{4}-$ 1,o g; $\mathrm{KCl}-0,5 \mathrm{~g} ; \mathrm{MgSO}_{4}-0,2 \mathrm{~g} ; \mathrm{CaCl}_{2}-$ o,1 g; ekstrakt drożdżowy- 0,5; $1000 \mathrm{ml}$ wody destylowanej, $\mathrm{pH}$ 7,4 z dodatkiem pasków FP $(0,5 \times 8 \mathrm{~cm})$. Hodowle pasteryzowano przez $15 \mathrm{~min} w$ tem. $85^{\circ} \mathrm{C}$, następnie inkubowano przez $28 \mathrm{dni}$ w temp. $28^{\circ} \mathrm{C}$. Liczebność WBMPBC odczytywano makroskopowo na podstawie nadtrawienia bibuły 
Tabela 1. Właściwości chemiczne gleby spod uprawy wiśni i jabłoni

\begin{tabular}{|c|c|c|c|c|c|c|c|c|c|c|c|c|}
\hline \multirow{2}{*}{ Lp. } & \multirow{2}{*}{$\begin{array}{c}\text { Kombinacje } \\
\text { nawozowe } \\
\text { (proporcje } \\
\text { wagowe) }\end{array}$} & \multirow[t]{2}{*}{$\mathrm{pH}$} & \multicolumn{10}{|c|}{ Zawartość pierwiastków (mg kg-1) } \\
\hline & & & C & $\mathrm{N}$ & $\mathrm{P}$ & K & $\mathrm{Mg}$ & $\mathrm{B}$ & $\mathrm{Cu}$ & $\mathrm{Fe}$ & $\mathrm{Mn}$ & $\mathrm{Zn}$ \\
\hline 0. & Kontrola & 6,4 & 0,65 & 0,07 & 23,4 & 59 & 53,2 & 3,02 & 3,45 & 535 & 63,3 & 58,7 \\
\hline 1. & $\begin{array}{l}\text { Węgiel brunatny } \\
(1)+\text { Pleurotus } \\
\text { ostreatus }(0,08)\end{array}$ & 6,2 & 1,12 & 0,09 & 35,6 & 102,4 & 52,9 & 2,99 & 3,51 & 513 & 59,1 & 57,1 \\
\hline 2. & $\begin{array}{l}\text { Węgiel brunatny } \\
(1)+\text { Pleurotus } \\
\text { ostreatus }(0,08) \\
+\operatorname{EM}(0,08)\end{array}$ & 6,3 & 1,08 & 0,08 & 34,7 & 107,3 & 54,1 & 2,88 & 3,54 & 499 & 58,9 & 56,9 \\
\hline & $\mathrm{HSD}_{\alpha=0.05}$ & 0,16 & 0,21 & 0,096 & 3,12 & 12,4 & 4,29 & 0,31 & 0,29 & 34,2 & 4,71 & 5,02 \\
\hline
\end{tabular}

Tabela 2. Liczebność WBMPBC (jtk) w gramie suchej masy gleby (s. m. g.) pobranej spod uprawy badanych roślin

\begin{tabular}{|c|c|c|c|c|c|c|c|}
\hline \multirow{3}{*}{\multicolumn{2}{|c|}{ Lp. Nawóz }} & \multicolumn{3}{|c|}{ Wiśnia } & \multicolumn{3}{|c|}{ Jabłoń } \\
\hline & & \multirow{2}{*}{$\begin{array}{c}\text { Ryzosfera } \\
515,1\end{array}$} & \multirow{2}{*}{$\begin{array}{c}\text { Gleba pozaryzos. } \\
9,99\end{array}$} & \multirow{2}{*}{$\begin{array}{r}\mathrm{HSD}_{\alpha=0.05} \\
32,56\end{array}$} & \multirow{2}{*}{$\begin{array}{r}\text { Ryzosfera } \\
546,40\end{array}$} & \multicolumn{2}{|c|}{ Gleba pozaryzos. $\mathrm{HSD}_{\alpha=0.05}$} \\
\hline & & & & & & 22,2 & 22,29 \\
\hline 1. & $\begin{array}{l}\text { Węgiel } \\
\text { brunatny } \\
+ \text { Pleurotus } \\
\text { ostreatus }\end{array}$ & 3186,9 & 27,09 & 179,53 & 502,46 & 270,9 & 43,78 \\
\hline 2. & $\begin{array}{l}\text { Węgiel } \\
\text { brunatny } \\
+ \text { Pleurotus } \\
\text { ostreatus } \\
+ \text { EM }\end{array}$ & 171,7 & 27,35 & 25,92 & 262,00 & 49,2 & 22,38 \\
\hline & $\alpha=0.05$ & 165,96 & 10,415 & $x$ & 26,64 & 40,73 & $x$ \\
\hline
\end{tabular}

filtracyjnej na granicy fazy płynnej i gazowej stosując tabele statystyczne McCrady'ego dla trzech powtórzeń. Wyniki badań zweryfikowano statystycznie z wykorzystaniem jednoczynnikowej analizy wariancji stosując program Statgraphics 4.o. HSD (honest significant difference) wyznaczono testem Tuk'eya przy $\alpha=0,05$.

\section{Wyniki}

Komposty wprowadzone do gleby pod uprawę wiśni i jabłoni zwiększyły w niej zawartość węgla organicznego oraz przyswajalnych form fosforu i potasu w stosunku do kontroli. Natomiast nie wpłynęły na zawartość azotu, magnezu i mikroelementów w glebie (Tab. 1).

Zastosowane komposty w zależności od użytych do procesu kompostowania składników w różny sposób kształtowały liczebność badanych drobnoustrojów w glebie pod uprawą roślin testowych, co przedstawia tabela 2. Obydwa komposty dodane pod uprawę wiśni istotnie zwiększyły liczebność badanych bakterii w glebie pozaryzosferowej w porównaniu do obiektu 
Tabela 3. Średnia liczebność WBMPBC (jtk) w gramie s. m. g. ryzosferowej i pozaryzosferowej

\begin{tabular}{llcc}
\hline & & \multicolumn{2}{c}{ Roślina } \\
\cline { 3 - 4 } Lp. & Gleba & Wiśnia & Jabłoń \\
\hline 1. & Ryzosferowa & 335,20 & 436,97 \\
\hline 2. & Pozaryzosferowa & 21,48 & 114,10 \\
\hline$H S D_{\alpha=0.05}$ & & 276,64 & 328,76 \\
\hline
\end{tabular}

kontrolnego, natomiast tylko kompost nr 1 (węgiel brunatny + vinassa + Pleurotus ostreatus) zwiększył liczebność bakterii w glebie ryzosferowej wiśni. Dodatni wpływ wspomnianego kompostu na liczebność bakterii zaobserwowano również dla gleby pozaryzosferowej jabłoni. Kompost z miału z węgla brunatnego, grzybni P. ostreatus z dodatkiem preparatu EM (nr 2) ograniczył liczebność badanych bakterii celulolitycznych w ryzosferze wiśni i jabłoni (Tab. 2.). Średnia liczebność badanej grupy drobnoustrojów była istotnie wyższa w glebie ryzosferowej niż w glebie pozarysosferowej dla obu upraw (Tab. 3.).

\section{Dyskusja}

Liczebność drobnoustrojów w glebie, w tym WBMPBC zależy od wielu czynników abiotycznych m.in. właściwości fizycznych, chemicznych, czy zabiegów agrotechnicznych (Kumar i in. 2011). Użyte do badań komposty poprawiły właściwości chemiczne gleby pod uprawą drzew owocowych, co przejawia się w zwiększeniu zawartości węgla organicznego, potasu i fosforu w porównaniu do obiektu kontrolnego. Korzystny wpływ aplikacji kompostów (przygotowanego z opadów po produkcji roślinnej i obornika) na właściwości fizykochemiczne gleby stwierdzili Valarini i in. (2009). Autorzy wykazali wzrost zawartości składników pokarmowych oraz poprawę struktury gleby pod wpływem dodatku testowanego kompostu. Ponadto zwiększenie zawartości składników pokarmowych przy stosowaniu kompostów odnotowali również Albaladejo (Albaladejo i in. 2009), którzy w swoich badaniach zajmowali się porównaniem wpływu dwóch kompostów (nr 1 przygotowany z rozkładu roślin nr 2 przygotowany z rozkładu roślin z dodatkiem osadu ściekowego) na właściwości gleby.

Przeprowadzone przez nas badania wykazały różnicę w liczebności badanej grupy mikroorganizmów zasiedlających glebę ryzosferową i pozaryzosferową w próbkach pobranych spod jabłoni i wiśni. Podobne relacje pomiędzy obiema strefami gleby odnotowali wcześniej inni autorzy (Pandey i Palni 2007; Morgan i in. 2005).

Zwiększona liczebność sporowych, mezofilnych drobnoustrojów celulolitycznych w glebie ryzosferowej może być spowodowana obecnością złuszczonych komórek systemu korzeniowego, zwanych komórkami granicznymi korzenia (KGK), które zawierają celulozę będącą źródłem węgla i energii dla badanych przez nas mikroorganizmów (Wang i in. 2014). Dodatkowo na tak dużą liczebność drobnoustrojów w glebie ryzosferowej mogą mieć wpływ wydzieliny korzeniowe wiśni i jabłoni tj. śluz szczególnie bogaty w łatwo przyswajalne związki węgla, witaminy, czy inne związki biologicznie aktywne korzystnie oddziaływujące na populacje badanych drobnoustrojów w ryzosferze (Shi i in.2011).

Zastosowany kompost nr 1 (węgiel brunatny + grzybnia Pleurotus ostreatus) wpłynął istotnie na zwiększenie liczebność bakterii celulolitycznych w ryzosferze 
i pozaryzosferowej wiśni w porównaniu z obiektem kontrolnym. Podobne relacje zaobserwowano w przypadku liczebności badanej grupy drobnoustrojów w glebie pozaryzosferowej jabłoni. W literaturze korzystny wpływ dodatku kompostu (przygotowany ze słomy pszenicy i obornika) do gleby na wzrost biomasy mikroorganizmów opisują Valarini i in. (2009).

W ryzosferze jabłoni i wiśni najmniejszą liczebność badanej grupy drobnoustrojów odnotowano w glebie z dodatkiem kompostu przygotowanego z miału węgla brunatnego i słomy przerośniętej grzybnią wegetatywną Pleurotus ostreatus i preparatem EM (efektywne mikroorganizmy). W skład preparatu EM wchodzą głównie bakterie z rodzaju Lactobacillus i Bifidobacterium, oraz promieniowce i drożdże, które mogą syntetyzować substancje antybiotyczne, w tym bakteriocyny, które zmniejszają liczebność bakterii. W związku z powyższym zastosowany preparat z EM mógł zredukować liczebność WBMPBC w glebie w stosunku do pozostałych wariantów nawozowych. Uzyskane przez autorów wyniki znajduja potwierdzenie we wcześniejszych badaniach Górskiej (2010). Autorka dodając do gleby komposty przygotowane $\mathrm{z}$ trocin jesionowych z dodatkiem osadu ściekowego z preparatem EM wykazała, że wpłynęły one na zmniejszenie liczebności WBMPBC w stosunku do obiektu z kompostem z trocin z jesiony i osadu ściekowego bez EM (Górska 2010).

\section{Wnioski}

1. Użyte komposty zwiększyły zawartość C, P, K w badanej glebie.

2. Dodatek kompostu przygotowanego na bazie miału węgla brunatnego i Pleurotus ostreatus w większości przypadków badanych próbek wpłynął korzystnie na liczebność WBMPBC.

3. W glebie ryzosferowej obu roślin dodatek preparatu EM do kompostu spodował spadek liczebności badanej grupy drobnoustrojów.

\section{Bibliografia}

Albaladejo J., Garcia C., Ruiz-Navarro A., Garcia-Franco N., Barbera G., 2009, Effects of organic composts on soilproperties: Comparative evaluation of source-separated and non-source separated composts, 2-10, "1st Spanish National Conference on Advances in Materials Recycling and Eco-Energy", Madrid, Nov 12-13.

Asha B.M, Revathi M., Yadav A., Sakthivel N., 2012, Purification and characterization of a thermophilic cellulase from a novel cellulolytic strain, Paenibacillus barcinonensis., Journal of Microbiology and Biotechnology, 22 (11): 1501-1509.

de Castro A.L.M, Vollú R.E, Peixoto R.S, Grigorevski-Lima A.L, Coelho R.R, Bon E.P, Rosado A.S, Seldin L., 2011, Cellulolytic potential of a novel strain of Paenibacillus sp. isolated from the armored catfish Parotocinclus maculicauda gut., Brazilian Journal of Microbiology, 42: 1608-1615.

Emtiazi G., Pooyan M., Shamalnasab M., 2007, Cellulase activities in nitrogen fixing Paenibacillus isolated from soil in n-free media., World Journal of Agricultural Sciences, 3: 602-608.

Górska E.B, 2010, Effect of compost made from lignocellulosic waste on biological activity of the soil: habilitation thesis, Warsaw Univeristy of Life Sciences. Warsaw, Poland.

Kumar A., Prakash A., Johri B.N, 2011, Bacteria in agrobiology: crop ecosystems. Bacillus as PGPR in Crop Ecosystem, Springer, Berlin, pp: 37-59.

Kumar D., Ashfaque M., Muthukumar M., Singh M., Garg N., 2012, Production and characterization of carboxymethyl cellulase from Paenibacillus polymyxa using mango peel as substrate., Journal of Environmental Biology, 33: 81-84.

Kwiatkowska J., Sokołowska Z., Maciejewska A, 2006, Selected physical and chemical properties for evaluating Wegiel brunatnys used for soil reclamation, International Agrophysics, 20:121-128.

Lisdiyanti P., Suyanto E., Gusmawati N.F., Rahayu W., 2012, Isolation and characterization of cellulase produced by cellulolytic bacteria from peat soil of Ogan Komering Ilir, South Sumatera., International Journal of Environment and Bioenergy, 3(3): 145-153.

Moon J.C., Jung X.J., Jung J.H, Jung H.S, Cheong Y.R, Jeon C.O, Lee K.O, Lee S.Y, 2011, Paenibacillus sacheonensis sp. nov., a xylanolytic and cellulolytic bacterium isolated from tidal flat sediment, 
International Journal of Systematic and Evolutionary, 61: 2753-2757.

Morgan J. A.W, Bending G.D, White P.J., 2005, Biological costs and benefits to plant-microbe interactionsin the rhizosphere., Journal of Experimental Botany, 56: 1729-1739.

Pandey A., Palni L.M.S, 2007. The rhizosphere effect in trees of the Indian Central Himalaya with special reference to altitude., Applied Ecology and Environmental Research, 5(1): 93-102.

Shi S., Richardson A.E., O'Callaghan M., DeAngelis K.M., Jones E.E., Stewart A., Firestone M.K, Condron L.M., 2011, Effects of selected rootexudate components on soil bacterial communities. FEMS., Microbiology Ecology, 77: 600-610.

Valarini P.J, Curaqueo G., Seguel A., Manzano K., Rubio R., Cornejo P., Borie F., 2009, Effect of compost application on some properties of volcanic soil from central south Chile. Chilean ., Journal of Agricultural Research, 69 (3): 416-425.

Wang L.K, Chu H.W., Li Z.Y., Wang J, Li J.T., QiaoY., Fu Y.R., Mou T.M., Chen C.L. Xu J., 2014, Origin and development of the root cap in rice, Plant Physiology, 166: 603-613.

Yin L.J., Lin H.H., Xiao Z.R., 2010, Purfication and characterization of a cellulase from Bacillus subtilis YJ1., Journal of Marine Science and Technology, 18: 466-471.

Zhen Z., Liu H., Wang N., Guo L., Meng J., Ding N., Wu G,. Jiang G., 2014, Effects ofmanure compost application on soil microbial community diversity and soil microenvironments in a temperate cropland in China, Plos One, doi:10.1371/journal. pone. 0108555 .

\section{The number of facultative, anaerobic, mesophilic, spore-forming cellulolytic bacteria in the soil fertilized with compost made from addition of powdered brown coal under cultivation of the fruit trees}

\section{Summary}

Ecology of facultative anaerobic, mesophilic, spore-forming and cellulolytic bacteria (FAMSCB) is poorly understood. In the literature, there are only scant information about the impact of fertilization and type of the crop on the occurrence of FAMSCB. The aim of our study was to demonstrate the effect of the addition of various brown coal fine-based composts on a chemical properties and the occurrence of in the bulk and rhizosphere soil from selected plants. Soil under the experimental plants was slightly acidic, and did not differ in macronutrient content. The number of investigated groups of microorganisms depended on the type of compost and ranged from 9.99 to 3186.9 cfu (colony forming units) per gram of dry soil. All composts stimulated the number of cellulolytic bacteria in a bulk soil. In the case of rhizosphere soil, compost containing effective microorganisms (EM) reduced the number of FAMSCB. The largest number of investigated rizosphere microorganisms were found in the cultivation of cherries, fertilized with compost prepared from brown fine with waste from the production of fruiting bodies of Pleuretus ostreatus (3186.9 cfu per gram of dry soil).

\section{Key words}

Brown coal, cellulas, composts, FAMSCB 